\title{
Occurrence of Atrazine Biodegrading Bacterium "Ochrobactrum oryzae" In Agricultural Wastewater
}

\author{
Amany M.M. Reyad, T. E.E. Radwan\#, W. M. Ibrahim* and A. M.M. Essa \\ Department of Botany, Faculty of Science, Fayoum University and * Botany \& Microbiology \\ Department, Faculty of Science, Damanhour University, Damanhour, Egypt.
}

\begin{abstract}
TRAZINE is the most extensively used herbicide that restrains photosynthesis of broad leaf and grassy weeds. In consequence of ground and surface water contamination with atrazine, humans and wildlife might be at risk. In the current investigation, an atrazinedegrading bacterium was isolated from agricultural drainage ditches (Fayoum, Egypt) using enrichment technique. According to the morphological, biochemical and 16S rDNA gene sequencing, the bacterial isolate was identified as Ochrobactrum oryzae. Using atrazine as sole carbon and nitrogen source, a pure culture of $O$. oryzae was grown in minimum media. The impact of atrazine concentration as well as temperature and $\mathrm{pH}$ on the bacterial growth and atrazine degradation rate was studied. The greatest potential for atrazine degradation $(83.5 \%)$ was attained at concentration $400 \mathrm{ppm}$ of atrazine within 9 days at $\mathrm{pH}$ value 9.0 and temperature $30^{\circ} \mathrm{C}$. Consequently, $\mathrm{O}$. oryzae can be applied conveniently for the cleanup of agricultural wastewater contaminated with high levels of atrazine.
\end{abstract}

Keywords: Ochrobactrum oryzae, 16S rDNA, Wastewater, Atrazine, Biodegradation.

\section{Introduction}

The accumulation of toxic pesticides in water and soil represents a prospective environmental concern. The s-triazine herbicides are the most commonly used pesticides in agriculture for several countries and probably it is the most commonly used herbicide in the world. Atrazine, 2-chloro4-(ethylamine)-6-(isopropyl amine)-s-triazine, a member of s-triazine group of herbicides is used for the control of annual and perennial grassy or broad leaf weeds in major crops due to its low cost and high effectiveness (Shahitha, 2012). Atrazine strongly reduces photosynthesis via stopping the electron transport in photosystem II resulting in the demolition of chlorophyll (Christopher et al., 2010).<smiles>CCNc1nc(Cl)nc(NC(C)C)n1</smiles>

6-chloro- $\mathrm{N}_{2}$-ethyl- $\mathrm{N}_{4}$-isopropyl-1,3,5triazine-2,4-diamine
Atrazine is non-volatile and its half-life is about 200 days but it varies from 21 days to 1 year depending on the environmental factors such as $\mathrm{pH}$ of the soil, type of soil, moisture content, temperature and the microbial communities (Zhang et al., 2012). Due to the excessive use and the high persistence of atrazine, it is moved to water bodies such as rivers, lakes and drinking water supplies and it had also been found in ground waters (Spalding et al., 1994). The potential contamination of water resources and soil with atrazine may cause pollution to the environment and bring enormous harm to human and other animals as it can be concentrated by plants and transferred to the food chain (Topp et al., 2000). .

Some studies had reported atrazine as one of the endocrine disruptors (Moore \& Waring, 1998) and as a probable human carcinogen (Luciane et al., 2010). Moreover, atrazine was found to be the reason for low sperm levels in men, the premature birth, miscarriage and various birth defects in humans (Ackerman, 2007 and Pathak \& Dikshit, 2011). Therefore an efficient remediation strategy for atrazine polluted environments is a vital task for a clean and safe environment. Some physiochemical methods have been used for the elimination of atrazine from the contaminated environment such

"Corresponding author email: tsd00@fayoum.edu.eg, Mobile: +201115378355,

Fax: +2084-2154835 - P.O.: 63514 Al Fayoum, Egypt.

DOI :10.21608/ejbo.2017.647.1032

C2017 National Information and Documentation Center (NIDOC) 
as adsorption, reduction-oxidation, dechlorination, photolysis, reverse osmosis (Ahalya et al., 2003). However, these methods are costly and produce many toxic intermediates.

Bioremediation has attracted increasing attention as a harmless, effectual, and economical biotechnological approach for herbicide elimination (Chen et al., 2011 and Essa et al., 2016). There have been several reports on atrazine mineralization by wide varieties of bacteria such as Pseudomonas, Acinetobacter, Agrobacterium, Rhodococcus and Arthrobacter (Vibber et al., 2007; Li et al., 2008; Siripattanakul et al., 2009; Arbeli \& Fuentes, 2010 and El Sebai et al., 2012). The capability of microorganisms to utilize atrazine as a carbon, energy and/or nitrogen source was clearly demonstrated (Struthers et al., 1998; Rousseaux et al., 2001 and Devers et al., 2007). Some bacterial strains metabolized atrazine to diethylatrazine or hydroxyatrazine, while others mineralized it by cleavage the ring. The catabolic pathway, enzymes and corresponding genes involved in atrazine degradation, were characterized in some bacterial strains (Mandelbaum et al., 1995; Sene et al., 2010 and Wang et al., 2011).

Although atrazine was prohibited in the European Union in 2003 (Bethsass \& Colangelo, 2006), it is still used as a major herbicide in Egypt. Exploration of atrazine-degrading microorganisms is of immense importance to reduce or eliminate the negative consequences of this compound to human health and ecosystem. The objectives of the present study were to (i) Isolate and characterize atrazine resistant bacteria from contaminated agricultural wastewater and (ii) Investigate the optimum growth and degradation conditions of these isolates in order to be used for bioremediation of the polluted environments.

\section{Materials and Methods}

\section{Chemicals}

Atrazine (99\% pure) was purchased from Riedelde Haën, Sigma-Aldrich, Seelze, Germany. All other chemicals purchased are of analytical grade from Fluka AG, Buchs, Switzerland.

\section{Growth Media and Culture conditions}

The mineral salt medium (MSM) used in this study contained $\mathrm{K}_{2} \mathrm{HPO}_{4}(0.4 \mathrm{~g} / \mathrm{L}), \mathrm{KH}_{2} \mathrm{PO}_{4}(0.2$ $\mathrm{g} / \mathrm{L}), \mathrm{NaCl},(0.1 \mathrm{~g} / \mathrm{L}), \mathrm{MgSO}_{4} \cdot 7 \mathrm{H}_{2} \mathrm{O}(0.5 \mathrm{~g} / \mathrm{L}), \mathrm{MnCl}_{2}$ $(0.01 \mathrm{~g} / \mathrm{L}), \mathrm{Fe}_{2}\left(\mathrm{SO}_{4}\right)_{3}(0.01 \mathrm{~g} / \mathrm{L}), \mathrm{Na}_{2} \mathrm{MoO}_{4}(0.01$ $\mathrm{g} / \mathrm{L})$ and $1 \mathrm{ml}$ of trace element solution per liter (Singh et al., 2004). Atrazine was used at different concentrations as a sole carbon and nitrogen source. The liquid mineral salt medium was supplemented with $2 \%(\mathrm{w} / \mathrm{v})$ agar for the preparation of solid medium. A Stock solution of atrazine was prepared with a concentration $500 \mathrm{ppm}$ and was diluted to the required concentrations for the degradation studies.

\section{Isolation of atrazine-degrading bacterium}

This experiment was carried out to select atrazine tolerant bacterial isolates. The agriculture wastewater $(500 \mathrm{~mL})$ was collected from El-Batts drain, Fayoum, Egypt. The sample was centrifuged at 10,000 rpm for $10 \mathrm{~min}$ and reconstructed with $10 \mathrm{~mL}$ sterilized $\mathrm{dH}_{2} \mathrm{O}$. Liquid MSM medium (45 mL) supplemented with atrazine $(200 \mathrm{ppm})$ was inoculated with $5 \mathrm{~mL}$ of bacterial suspension and incubated for $48 \mathrm{~h}$ inside shaking incubator $(120 \mathrm{rpm})$ at $30^{\circ} \mathrm{C}$. Aliquots were sub-cultured every 3 days for three times. The final culture was diluted and plated on atrazine agar plates. Developed colonies were repeatedly streaked on atrazine agar plates for isolation of pure cultures. Atrazine-degrading bacterial isolates were identified as colonies surrounded by a clear halo. The bacterial isolate designated ATT was chosen for this work because it is the most tolerant strain that can grow under elevated levels of atrazine (500 ppm). A pure culture of ATT bacterium was then stored in solid MSM media containing 100 ppm atrazine for further studies.

\section{Phenotypic characterization of ATT isolate}

The ATT isolate was tested for morphology, motility and Gram stain by phase contrast microscopy. Biochemical identification of the ATT isolate was performed using commercially identification systems API (BioMérieux, France). Prior to inoculation of each identification system, a $24 \mathrm{~h}$ bacterial culture re-inoculated onto NA plates to obtain isolated colonies for testing purposes. The API $20 \mathrm{NE}$ identification system is used for the identifying non-fastidious, non-enteric Gram-negative rods. Test strips were inoculated and incubated according to the instructions provided.

\section{Identification of the bacterial isolate ATT}

The atrazine-degrading isolate was identified using 16S rDNA gene sequencing technique. The genomic DNA was extracted according to Essa (2012). For the amplification of the 16S rDNA gene two primers were used; F1; AGA GTT TGA TCC TGG CTC AG and R1; GGT TAC CTT GTT ACG ACT T. The PCR mixture was prepared as the following; $10 \mu \mathrm{L}$ (10x) PCR buffer, $3 \mu \mathrm{L}(50 \mathrm{mM})$ $\mathrm{MgCl}_{2}, 1 \mu \mathrm{L}(20$ pmole/ $\mu \mathrm{L})$ of each primer, $1 \mu \mathrm{L}$ 
$(10 \mathrm{mM}) \mathrm{dNTPs}$ mixture, $0.5 \mu \mathrm{L}$ (2.5U) Taq DNA polymerase, $2 \mu \mathrm{L}$ total DNA extract, and the volume is completed to $100 \mu \mathrm{L}$ by $\mathrm{sdH}_{2} \mathrm{O}$. PCR was carried out for 35 cycles under the conditions described by Essa et al. (2016). PCR products $(10 \mu \mathrm{L})$ were mixed with loading buffer $(2 \mu \mathrm{L})$ and analyzed by electrophoresis $(15 \mathrm{~V} / \mathrm{cm}, 60 \mathrm{~min})$ on $0.7 \%$ agarose gel containing ethidium bromide $(0.5 \mu \mathrm{g} / \mathrm{mL})$ using TBE buffer. The amplified DNA fragments were sequenced at GATC Biotech, Constance, Germany. Furthermore, a phylogenetic tree was established using neighbourjoining technique using TREEVIEW software (1.6.6) derived from 16S rRNA gene sequences of some strains phylogenetically close to the isolated strain.

Optimization of the growth conditions and atrazine biodegradation by $O$. oryzae

Experiments aiming to study the effect of atrazine concentration on the bacterial growth were carried out in $250 \mathrm{~mL}$ flask containing $50 \mathrm{~mL}$ MSM enriched with various doses of atrazine $(100-500$ ppm). The medium was inoculated by $5 \mathrm{~mL}$ of bacterial cell suspension $(\mathrm{OD} 600 \mathrm{~nm}=0.6)$ and incubated on a rotary shaker $(120 \mathrm{rpm})$ at $30^{\circ} \mathrm{C}$ for 21 days. Cell growth in liquid media was determined spectrophotometrically by measuring the cultural optical density at $600 \mathrm{~nm}$ (OD600) at $24 \mathrm{~h}$ intervals over 20 days. In order to confirm the bacterial growth, the protein content of the bacterial cultures was determined according to Bradford (1976). To explore the impact of $\mathrm{pH}$ on the bacterial growth, experiments were conducted at different $\mathrm{pH}$ values (5, 7 and 9). Cultures supplemented with $400 \mathrm{ppm}$ atrazine as a sole carbon and nitrogen source were incubated as mentioned above. Simultaneously, the influence of temperature on the bacterial growth was investigated on MSM medium enriched with $400 \mathrm{ppm}$ atrazine at $\mathrm{pH}(9.0)$. Bacterial cultures were incubated at different temperatures $\left(20^{\circ} \mathrm{C}\right.$, $30^{\circ} \mathrm{C}$ and $37^{\circ} \mathrm{C}$ ). All the experiments were done in triplicates. The bacteria growth in liquid media was assayed spectrophotometrically as mentioned above. In order to measure the abiotic degradation of atrazine, Minimum salt media supplemented with equal concentrations of atrazine without bacterial inoculum were prepared and incubated under the same conditions.

\section{Analysis of the residual atrazine}

The capability of $O$. oryzae for atrazine biodegradation was determined at different temperatures and $\mathrm{pH}$ values after 12 days incubation in order to identify the optimum condition for atrazine degradation. The residual Atrazine was extracted according to the method of Liu (2003). About $50 \mathrm{~mL}$ of $90 \%$ methanol was added to 20 $\mathrm{mL}$ liquid culture and was left $24 \mathrm{~h}$. After that, the mixture was extracted two times with $50 \mathrm{~mL} \mathrm{CH}_{3} \mathrm{Cl}$. Then the received solution was concentrated under nitrogen flow to $1 \mathrm{~mL}$ to be determined by gas chromatography. A Hewlett-Packard, USA serial 6890 gas chromatograph equipped with electron detector (ECD, Radioisotope Nuclide 63Ni) and HP PAS-1701 column $25 \mathrm{~m}$ length $\times 0.32 \mathrm{~mm}$ (i.d.) $\mathrm{x}$ 0.52 thickness. Pure nitrogen was used as carrier gas $(2 \mathrm{~mL} / \mathrm{min})$. Detector, injector and column temperature was 250,240 and $225^{\circ} \mathrm{C}$, respectively. The atrazine degradation rate was calculated by the following formula:

$$
\mathrm{A}=[\mathrm{Ca}-\mathrm{Cb} / \mathrm{Ca}] \times 100
$$

where, (A) is the percentage of atrazine degradation, $(\mathrm{Ca})$ is the concentration of atrazine $(\mathrm{mg} / \mathrm{L})$ in the medium in absence of atrazine-degrading strain, $(\mathrm{Cb})$ is the concentration of atrazine $(\mathrm{mg} / \mathrm{L})$ in presence of atrazine-degrading strain.

\section{Statistics}

The data presented here are the mean values of three replications. Standard errors were calculated for all the values using MS Excel 2007.

\section{Results}

\section{Isolation of atrazine degrading bacteria}

The atrazine-degrading bacteria was isolated from agricultural drainage ditches in 2013 (Fayoum, Egypt) using enrichment technique. The bacterial isolate ATT was the most tolerant strain against high levels of atrazine (1200 ppm). Most agricultural fields are well drained, whereas hydrologic conditions in ditches can change widely. Agricultural drainage haves been reported to contain high levels of pesticides (Moore et al., 2008 and Moore et al., 2011). The microbial populations of the agricultural wastewater usually include some bacterial strains that can tolerate high concentrations of the toxic pesticides (Radwan et al., 2017). Moreover, these bacterial strains might have the capability to degrade and mineralize these compounds (Tyler et al., 2013).

\section{Identification of atrazine degrading bacteria}

A variety of morphological and biochemical assays were carried out to have a comprehensive view of the phenotypic characteristics of the bacterial isolate ATT as shown in Table 1. ATT Isolate was Gram-negative, motile, and non- 
spore forming rods. This isolate demonstrated positive results with catalase, cytochrome oxidase, lysine decarboxylase, urease, amylase, arginine dihydrolase, gelatinase, $\mathrm{NO}_{2}$ production, aceton production and tryptophane deaminase. Meanwhile, negative results were obtained with indole production, $\beta$-galactosidase, $\mathrm{H}_{2} \mathrm{~S}$ production, lipase, and ornithine decarboxylase. Simultaneously, the ATT isolate showed the capability to utilize glucose, mannitol, inositol, starch and citrate as a carbon source. The ATT isolate was identified as Ochrobactrum oryzae using 16S rDNA gene sequencing technique with maximum homology of $93 \%$ to Ochrobactrum oryzae strain: SP91A with accession no. AB41136 (Fig. 1). The phylogenetic tree of the atrazine degrading bacterial strain ATT and related bacterial species based on the 16S rDNA sequence was provided in Fig. 2. It can be clearly seen that the atrazine degrading strain (ATT) was included in the genus Ochrobactrum and closely related to the species oryzae.

The obtained data showed a remarkable capability of a pure culture of Ochrobactrum oryzae for atrazine degradation. The capability of Ochrobactrum sp. for the degradation of atrazine was recorded by many authors as a member of mixed atrazine transforming cultures. In 2007, Kolic et al. characterized atrazine-degrading bacterial community from contaminated soils of an agrochemical factory. The bacterial community consisted of two Arthrobacter strains in addition to Ochrobactrum sp. and Pseudomonas sp. Furthermore, Udikovic-Kolic et al. (2010) identified Ochrobactrum strain as a member of the bacterial population consisting of, Arthrobacter sp., Achromobacter sp. and Flavobacterium sp. This bacterial community demonstrated elevated competence for atrazine elimination.

\section{Optimization of the growth of Ochrobactrum oryzae and atrazine degradation}

The degradation of s-triazine pesticides by bacteria has been found to occur via different pathways ending with cyanuric acid as intermediate compound (De Souza et al., 1996 and Sadowsky et al., 1998). The cyanuric acid is further metabolized by bacteria via hydrolytic enzymes that ultimately release the nitrogen as ammonia (Cheng et al.,
2005). In order to specify the optimum growth conditions of Ochrobactrum oryzae, the effect of atrazine concentration, temperature, and $\mathrm{pH}$ value was investigated. Data in Fig. 3 showed the effect of atrazine concentration $(100-500 \mathrm{ppm})$ as a sole carbon and nitrogen source on the growth of O. oryzae. The maximum optical density (0.61) was recorded at $400 \mathrm{ppm}$ of atrazine after 12 days of incubation while the highest protein content $(284 \mathrm{mg} / \mathrm{L})$ was observed after 9 days at the same concentration of atrazine. Above or beyond this concentration, an obvious reduction in the optical density and protein content of the bacterial culture was recorded.

Regarding the effect of temperature on the growth of $O$. oryzae (Fig. 4) and atrazine degradation (Figure 6 and Table 2), the maximum bacterial optical density, protein content and atrazine degradation were demonstrated at $30^{\circ} \mathrm{C}$ after 9 days. At temperatures below $\left(20^{\circ} \mathrm{C}\right)$ or above $\left(37^{\circ} \mathrm{C}\right)$, clear inhibition in the optical density $(0.51 \& 0.36)$ and protein contents (185.6 \& 127.3). At the same time, a marked inhibition in the degradation efficiency of atrazine $(59.3 \% \& 20.1 \%)$ was recorded. These results are in agreement with those reported by Abigail et al. (2012) and Belal et al. (2013) who found that the optimum temperature for atrazine degradation by Cryptococcus laurentii and Pseudomonas fluorescens was $30^{\circ} \mathrm{C}$.

Simultaneously, the change in the $\mathrm{pH}$ value demonstrated a remarkable effect on the growth of $O$. oryzae. The effect of $\mathrm{pH}$ value on bacterial growth and atrazine degradation was shown in Fig. 5, 6 and Table 2. The maximum optical density $(0.69)$, protein content $(253.4 \mathrm{mg} / \mathrm{L})$ and atrazine degradation (83.5\%) was obtained at $\mathrm{pH} 9.0$ after 9 days. In the meantime, the recorded optical density $(0.19 \& 0.56)$, protein content $(43.9 \&$ $215.7 \mathrm{mg} / \mathrm{L})$ and atrazine degradation (16.2\%, $72.3 \%$ ) were significantly reduced at $\mathrm{pH}$ ranges 5.0 and 7.0. These outcomes are in harmony with the studies which clarified that soil $\mathrm{pH}$ was the most significantly related parameter for atrazine mineralization. At $\mathrm{pH}$ values lower than 6.5 , less than $25 \%$ of the initial atrazine was mineralized. The optimum $\mathrm{pH}$ for atrazine degradation was found to be between 7.0 and 9.0 (Clotaire \& Nikolaus, 1994 and Abigail et al., 2012). 
TABLE1. Biochemical characterizations of the atrazine degrading bacterial isolate ATT.

\begin{tabular}{|c|c|c|c|}
\hline Reaction & Result & Reaction & Result \\
\hline Morphological characters & & Fermentation of sugars & \\
\hline Gram staining & & Glucose & $+\mathrm{ve}$ \\
\hline Motility & -ve & Sucrose & -ve \\
\hline Cell shape & + ve & Mannitol & + ve \\
\hline Endospore formation & Rod & Inositole & $+\mathrm{ve}$ \\
\hline Biochemical characters & -ve & Sorbitol & -ve \\
\hline Enzyme profile & & Rhamnose & -ve \\
\hline$\beta$-galactosidase & & Melibiose & -ve \\
\hline Arginine dihydrolase & ve- & Amygdalin & -ve \\
\hline Lysine decarbolase & + ve & Arabinose & -ve \\
\hline Orenthine decarbolase & ve+ & Starch & $+\mathrm{ve}$ \\
\hline Urease & ve- & Citrate utilization & $+\mathrm{ve}$ \\
\hline Tryptophane deaminase & + ve & Other tests & \\
\hline Gelatenase & + ve & $\mathrm{H}_{2} \mathrm{~S}$ production & ve- \\
\hline Catalase & $+\mathrm{ve}$ & Acetoin production & $+\mathrm{ve}$ \\
\hline Amylase & + ve & Indole production & -ve \\
\hline Lipase & + ve & & \\
\hline Cytochrome xidase & -ve & & \\
\hline Nitrate reduction & + ve & & \\
\hline -To nitrite & -ve & & \\
\hline -To $\mathrm{N}_{2}$ gas & $+\mathrm{ve}$ & & \\
\hline
\end{tabular}




\begin{tabular}{|c|c|c|c|}
\hline АТT & 77 & 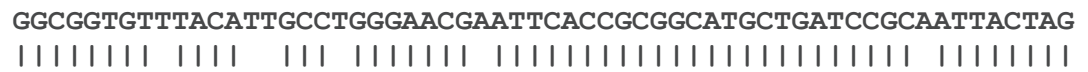 & 136 \\
\hline Sbjet & 1331 & GGCGGTGTGTACAAGGCCCGGGAACGTATTCACCGCGGCATGCTGATCCGCGATTACTAG & 1272 \\
\hline ATT & 137 & CGATTCCA-CTTCATGCACTCGAGTTGCAGAGTGCAATCCGAACTGAGATGGCTTTTGGA & 195 \\
\hline & & 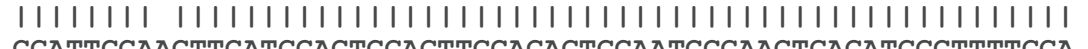 & \\
\hline Sbjct & 1271 & CGATTCCAACTTCATGCACTCGAGTTGCAGAGTGCAATCCGAACTGAGATGGCTTTTGGA & 1212 \\
\hline АTT & 196 & GATTAGCTCACACTCGCGTGCTCGCTGCCCACTGTCACCACCATTGTAGCACGTGTGTAG & 255 \\
\hline Sbjet & 1211 & 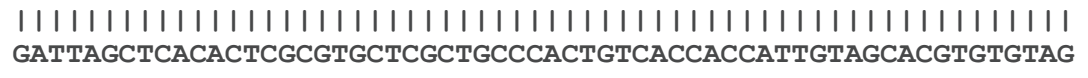 & 1152 \\
\hline АTT & 256 & 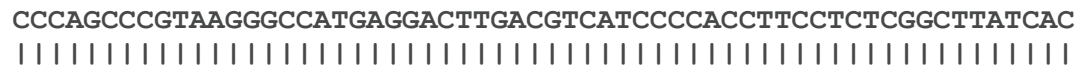 & 315 \\
\hline Sbjet & 1151 & CCCAGCCCGTAAGGGCCATGAGGACTTGACGTCATCCCCACCTTCCTCTCGGCTTATCAC & 1092 \\
\hline АTT & 316 & 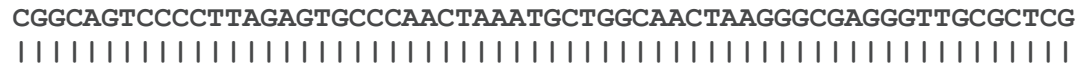 & 375 \\
\hline Sbjet & 1091 & CGGCAGTCCCCTTAGAGTGCCCAACTAAATGCTGGCAACTAAGGGCGAGGGTTGCGCTCG & 1032 \\
\hline АTT & 376 & 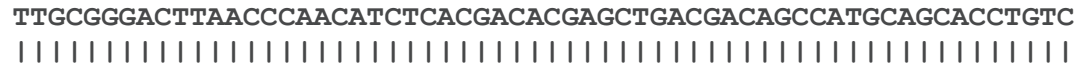 & 435 \\
\hline Sbjet & 1031 & TTGCGGGACTTAACCCAACATCTCACGACACGAGCTGACGACAGCCATGCAGCACCTGTC & 972 \\
\hline ATT & 436 & 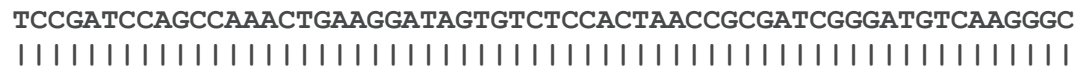 & 495 \\
\hline Sbjet & 971 & TCCGATCCAGCCAAACTGAAGGATAGTGTCTCCACTAACCGCGATCGGGATGTCAAGGGC & 912 \\
\hline АTT & 496 & $\begin{array}{l}\text { TGGTAAGGTTCTGCGCGTTGCTTCGAATTAAACCACATGCTCCACCGCTTGTGCGGGCCC } \\
111111111111111111111111111111111111111111111111111111111111\end{array}$ & 555 \\
\hline Sbjet & 911 & TGGTAAGGTTCTGCGCGTTGCTTCGAATTAAACCACATGCTCCACCGCTTGTGCGGGCCC & 852 \\
\hline АTT & 556 & 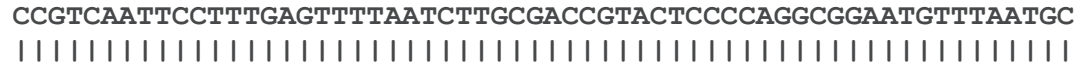 & 615 \\
\hline Sbjet & 851 & ССGTCAATTCCTTTGAGTTTTAATCTTGCGACCGTACTCCCCAGGCGGAATGTTTAATGC & 792 \\
\hline АТT & 616 & 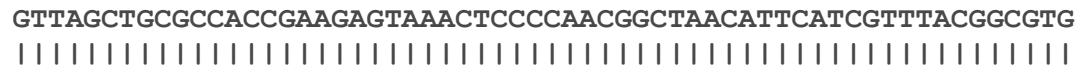 & 675 \\
\hline Sbjct & 791 & GTTAGCTGCGCCACCGAAGAGTAAACTCCCCAACGGCTAACATTCATCGTTTACGGCGTG & 732 \\
\hline АTT & 676 & 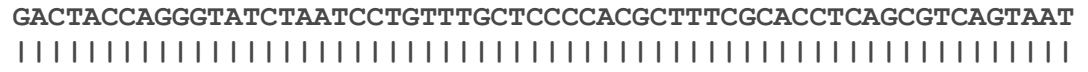 & 735 \\
\hline Sbjct & 731 & GACTACCAGGGTATCTAATCCTGTTTGCTCCCCACGCTTTCGCACCTCAGCGTCAGTAAT & 672 \\
\hline АTT & 736 & 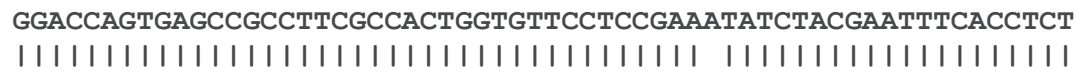 & 795 \\
\hline Sbjet & 671 & GGACCAGTGAGCCGCCTTCGCCACTGGTGTTCCTCCGAA-TATCTACGAATTTCACCTCT & 613 \\
\hline АTT & 796 & 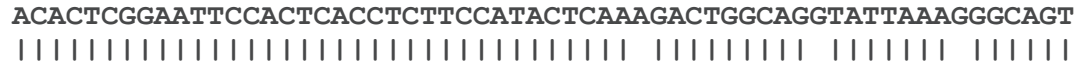 & 855 \\
\hline Sbjct & 612 & АСАCTCGGAATTCCACTCACСTCTTCCATACTCAA-GACTGGCAG-TATTAAA-GGCAGT & 556 \\
\hline АTT & 856 & 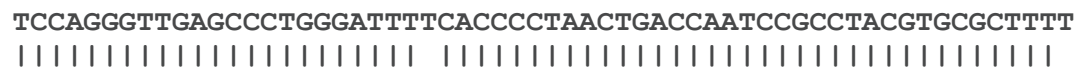 & 915 \\
\hline Sbjet & 555 & TCCAGGGTTGAGCCCTGGGATTT-САCСССTAACTGACCAATCCGCСTACGTGCGCTTT- & 498 \\
\hline АТT & 916 & 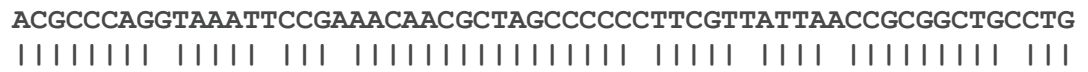 & 975 \\
\hline Sbjct & 497 & ACGCCCAG-TAAAT-CCG-AACAACGCTAGCCCCC-TTCGT-ATTA-CCGCGGCTG-CTG & 445 \\
\hline
\end{tabular}




\begin{tabular}{|c|c|c|c|}
\hline ATT & 976 & 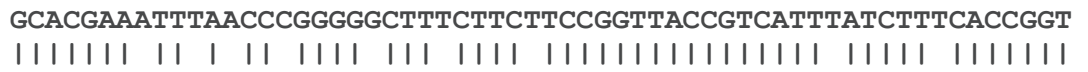 & 1035 \\
\hline Sbjct & 444 & GCACGAAGTT-AGCC-GGGG-CTT-CTTC-TCCGGTTACCGTCATT-ATCTT-CACC & 392 \\
\hline ATT & 036 & 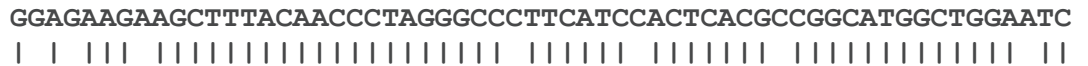 & 1095 \\
\hline Sbjet & 91 & G-A-AAG-AGCTTTACAACCCTAGGGCC-TTCATC-ACTCACG-CGGCATGGCTGGA-TC & 339 \\
\hline ATT & 096 & 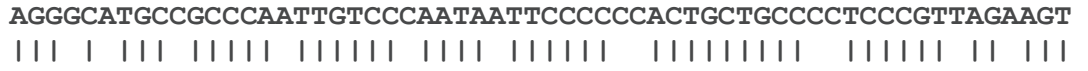 & \\
\hline Sbjc & 338 & AGG-CTTGC-GCCCA-TTGTCC-AATA-TTCCCC--ACTGCTGCC--TCCCGT-AGGAGT & 289 \\
\hline ATT & 6 & $\begin{array}{l}\text { ITGGTCCTCATTCCACATGGTGGGCTGTA: } \\
||||||||||||||||||||\end{array}$ & \\
\hline $\mathrm{Sbjc}$ & 288 & CTGGGCCGTG-TC-TCAGTCC-CAGTGTGG-CTG-ATCA-TCC-TCTC--AGA-CCAGCT & 239 \\
\hline АTT & 121 & AATGGGATTCGTCGCGCTTTGGATAGGCCGTTGAACCCCCAACCCAACTAGATCTAATCT & \\
\hline Sbjot & 23 & A-TGG-AT-CGTCG & 93 \\
\hline
\end{tabular}

Fig. 1. Partial DNA sequences of the 16S rDNA gene of the bacterial strain ATT isolated from agricultural wastewater and the corresponding gene of Ochrobactrum oryzae SP91A (accession number: AB841136).

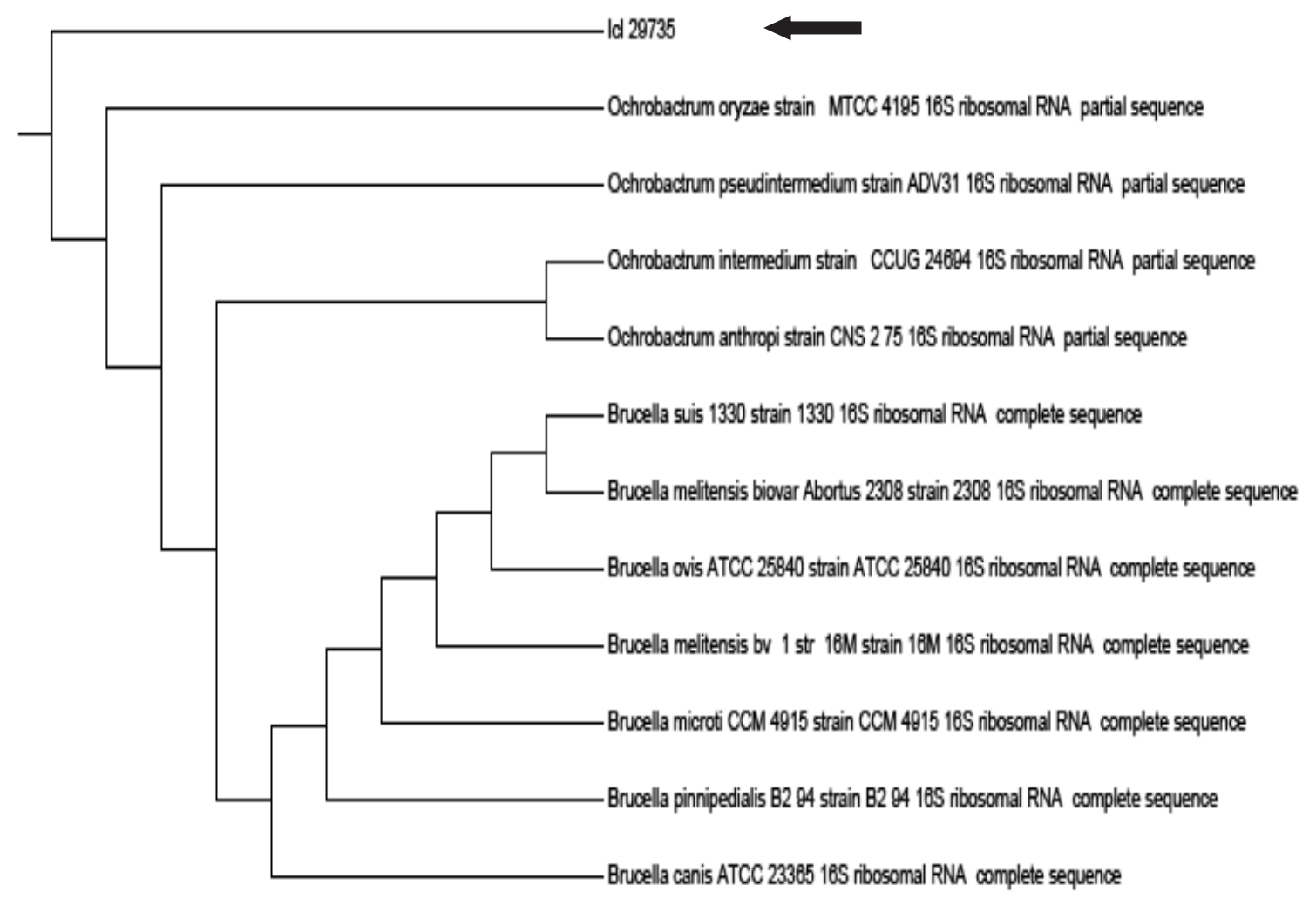

Fig. 2. Phylogenetic dendrogram obtained by distance matrix analysis of 16S rDNA sequences showing the position of the bacterial isolate ATT among phylogenetic neighbors. The black arrow indicates the position of ATT strain. 

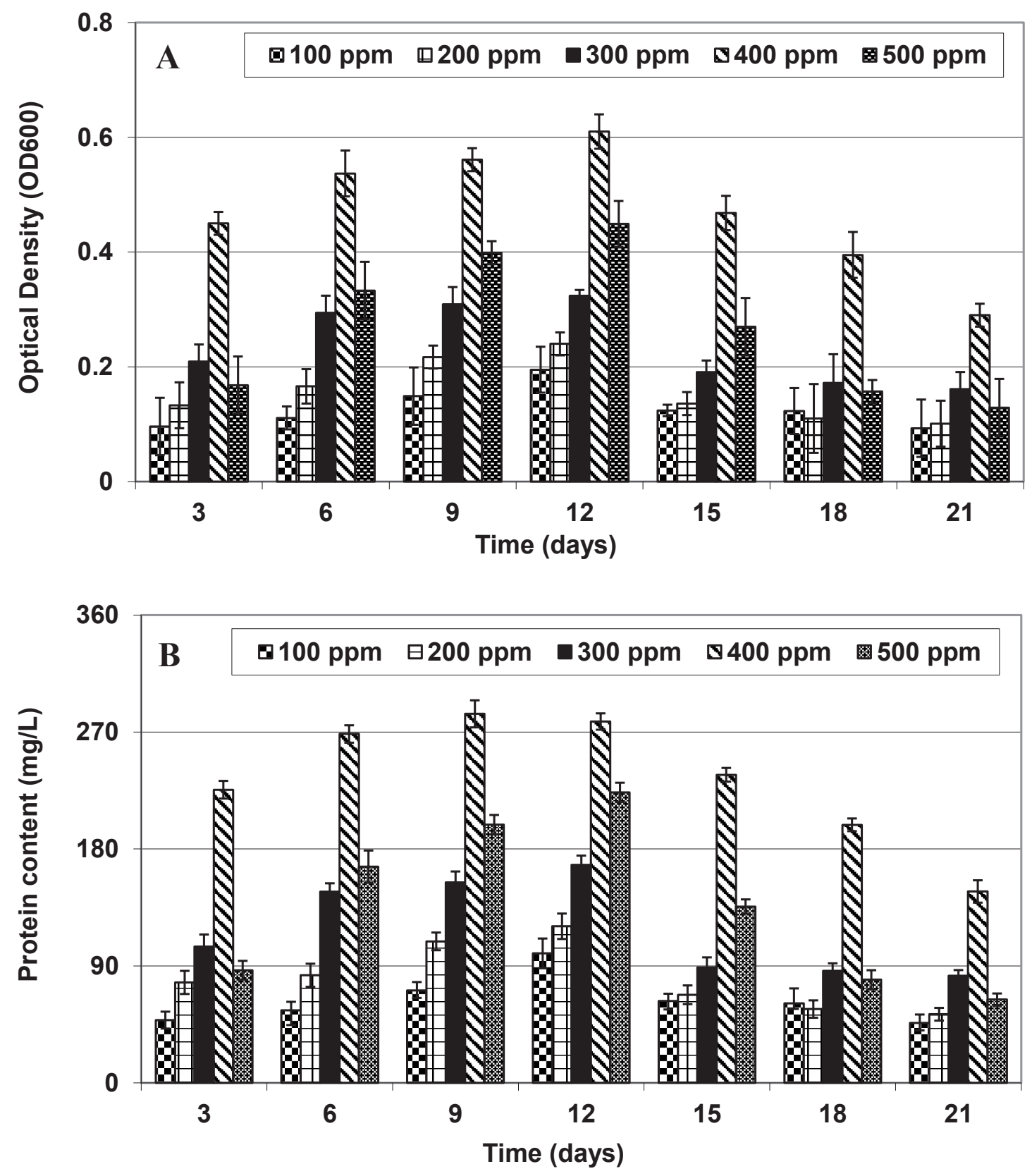

Fig. 3. Effect of atrazine concentration on the growth of Ochrobactrum oryzae, (A) represents the optical density $(O D 600 \mathrm{~nm})$ while $(B)$ represents the protein content $(\mathrm{mg} / \mathrm{L})$ of the bacterial growth. Atrazine was used as sole carbon and nitrogen source. Data are the means of three replicates and error bars represent the standard errors of the means. 

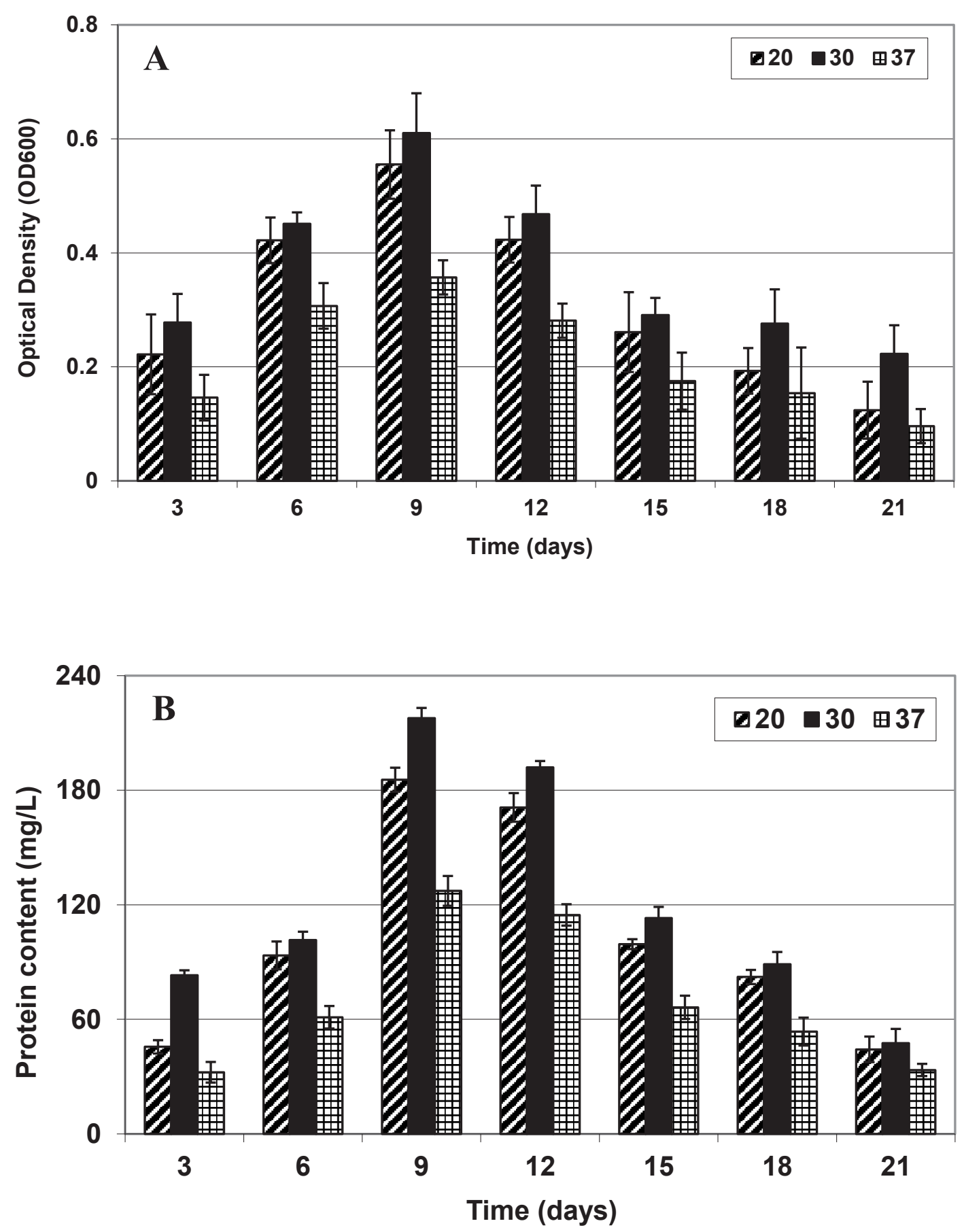

Fig. 4. Effect of temperature on the growth of Ochrobactrum oryzae, (A) represents the optical density (OD 600 $\mathrm{nm})$ while $(B)$ represents the protein content $(\mathrm{mg} / \mathrm{L})$ of the bacterial growth. Atrazine $(400 \mathrm{ppm})$ was used as sole carbon and nitrogen source. Data are the means of three replicates and error bars represent the standard errors of the means. 

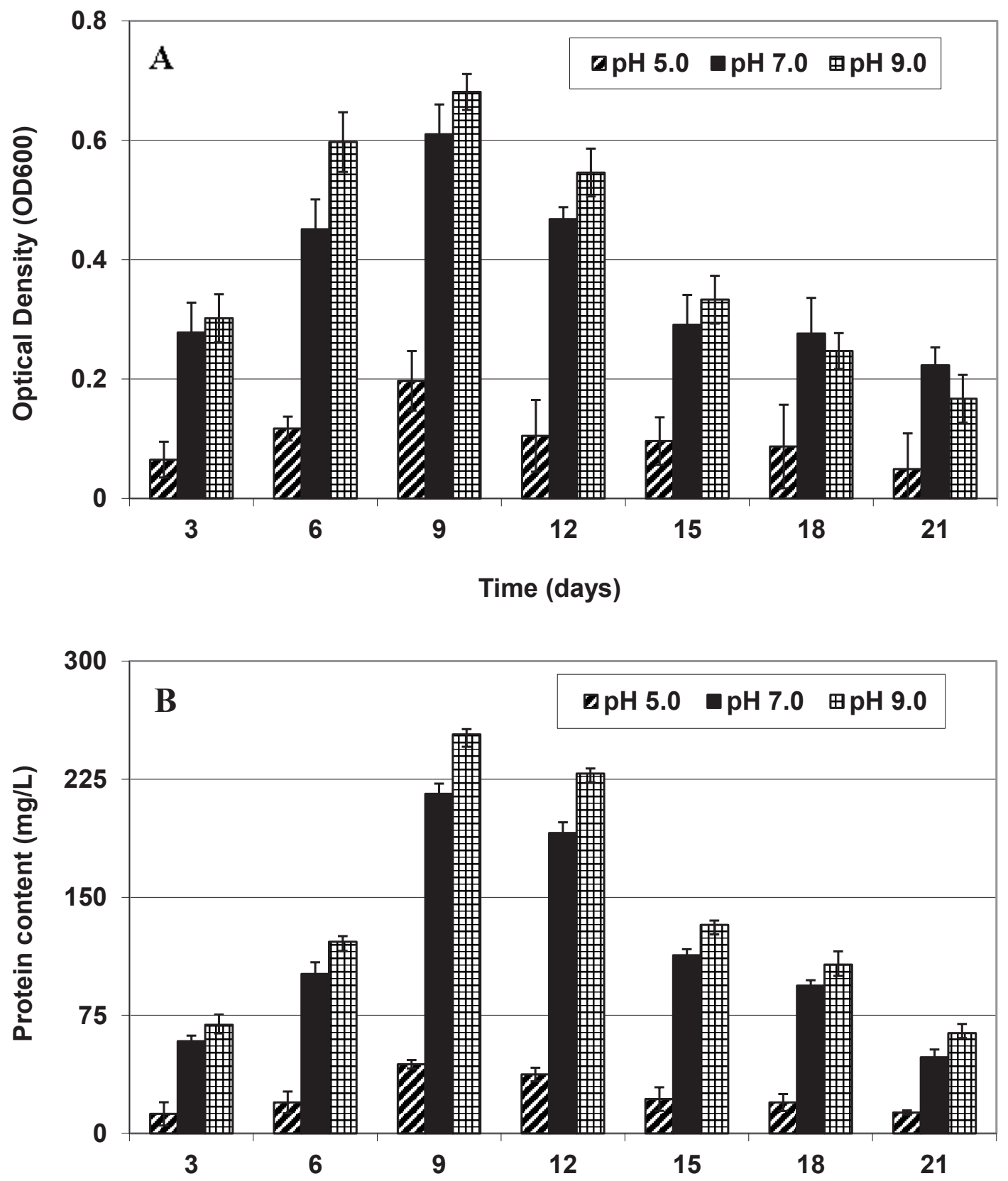

Fig 5. Effect of pH value on the growth of Ochrobactrum oryzae, (A) represents the optical density (OD $600 \mathrm{~nm})$ while $(B)$ represents the protein content $(\mathrm{mg} / \mathrm{L})$ of the bacterial growth. Atrazine $(400 \mathrm{ppm})$ was used as sole carbon and nitrogen source. Data are the means of three replicates and error bars represent the standard errors of the means. 
TABLE 2. The percentage of atrazine removal by Ochrobactrum oryzae under different temperatures and $\mathrm{pH}$ values after 9 days of incubation. The initial concentration was $386.3 \mathrm{ppm}$.

\begin{tabular}{lcccc}
\hline Treatment & & $\begin{array}{c}\text { Retention time } \\
(\mathbf{m i n})\end{array}$ & $\begin{array}{c}\text { Residual } \\
(\mathbf{p p m})\end{array}$ & $\begin{array}{c}\text { Removal } \\
\mathbf{( \% )}\end{array}$ \\
\hline \multirow{3}{*}{$\mathrm{pH}$ value } & 5.0 & 4.612 & 323.6 & 16.2 \\
& 7.0 & 4.605 & 123.2 & 72.3 \\
& 9.0 & 4.644 & 63.8 & 83.5 \\
Temperature & $20^{\circ} \mathrm{C}$ & 4.616 & 157.7 & 59.3 \\
\hline
\end{tabular}

A

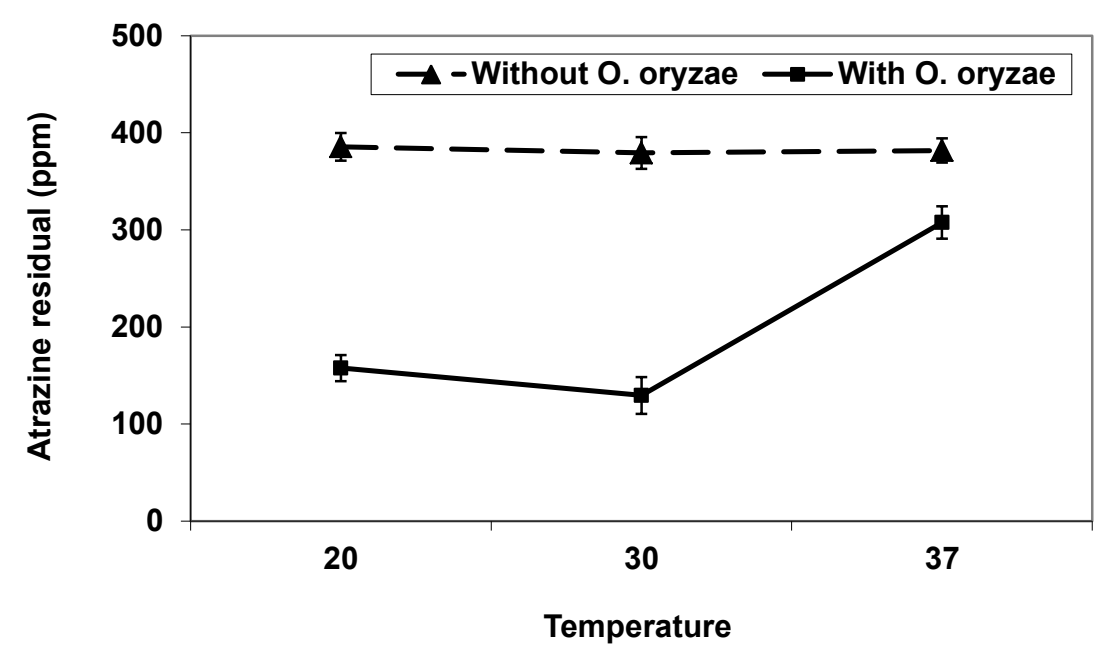

B

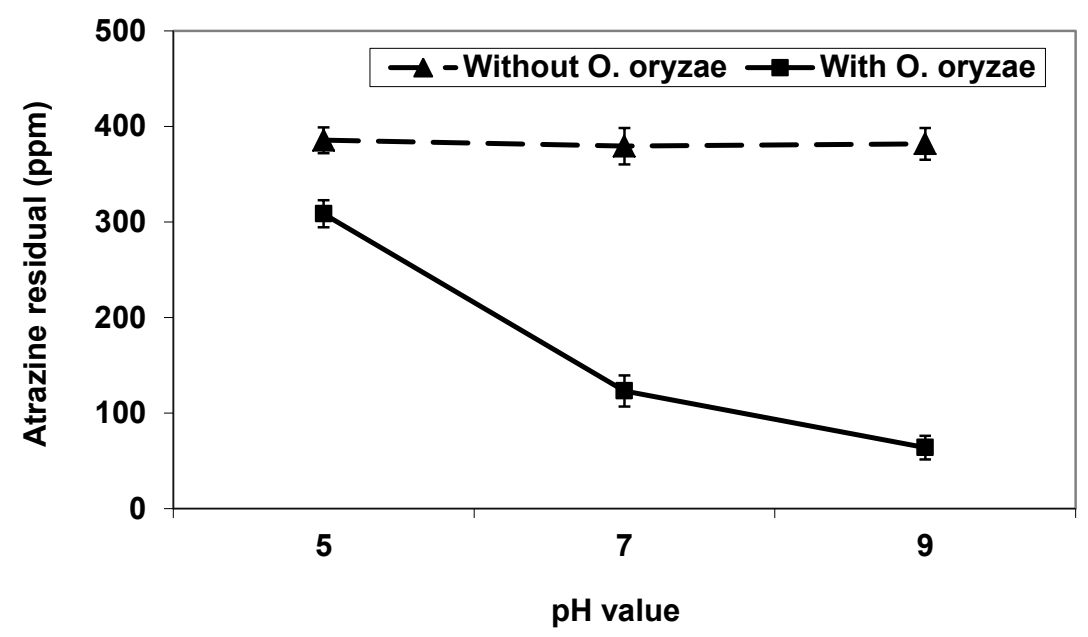

Fig.6. Optimization of atrazine degradation by Ochrobactrum oryzae, (A) represents the effect of temperature while (B) represents the effect of $\mathrm{pH}$ value on the biodegradation process after 9 days. Initial concentration of atrazine was $386.3 \mathrm{ppm}$. Data are the means of three replicates and error bars represent the standard errors of the means. 


\section{Conclusion}

An atrazine tolerant bacterial strain was isolated from agricultural drainage ditches by enrichment technique. This strain that was identified by 16S rDNA techniques as Ochrobactrum oryzae, showed a high capability to utilize atrazine as a sole carbon and nitrogen source. A remarkable rate of atrazine degradation was achieved at $\mathrm{pH}$ value 9.0 and temperature $30^{\circ} \mathrm{C}$ within 9 days. As a consequence, $O$. oryzae could be used efficiently for the environmental cleanup of agricultural wastewater contaminated with high levels of atrazine and limiting the amount of this herbicide carried into downstream ecosystems.

\section{References}

Abigail, E.A.M., Lakshmi, V. and Das, N. (2012) Biodegradation of atrazine by Cryptococcus laurentii isolated from contaminated agricultural soil. J. Microbiol. Biotech. Res. 2, 450-457.

Ackerman, F. (2007) The economics of atrazine. Int. $J$. Occu. Environ. Health, 13 (4), 437-445.

Ahalya, N., Ramchandra, T.V. and Kanamadi, R.D. (2003) Biosorption of heavy metals. Res. J. Chem. Environ. 7, 71-74.

Arbeli, Z. and Fuentes, C. (2010) Prevalence of the gene $\operatorname{trz} N$ and biogeographic patterns among atrazinedegrading bacteria isolated from 13 Colombian agricultural soils. FEMS Microbiol. Ecol. 73, 611-623.

Belal, E.B., Eissa, F.I., Zidan, N.A.,and Nasr, I.N. (2013) Bioremediation of atrazine-contaminated water and soils by Pseudomonas fluorescens. Int. J. Microbiol. Res. 4 (3), 241-252.

Bethsass, J. and Colangelo, A. (2006) European Union bans atrazine, while the United States negotiates continued use. Int. J. Occu. Environ. Health, 12, 260-267.

Bradford, M.M. (1976) A rapid and sensitive method for the quantition of microgram quantities of protein utilizing the principle of protein-dye binding. Anal. Biochem. 72, 248- 254.

Chen, S., Yang, L., Hu, M. and Liu, J. (2011) Biodegradation of fenvalerate and 3-phenoxybenoic acid by a novel Stenotrophomonas sp. Strain ZS-S01 and its use in bioremediation of contaminated soils. Appl. Microbiol. Biotechnol. 90,755-767.
Cheng, G., Shapir, N., Sadowsky, M.J. and Wackett, L.P. (2005) Allophanate hydrolase, not urease, functions in bacterial cyanuric acid metabolism. Appl. Environ. Microbiol. 71, 4437-4445

Christopher, D.N., Wazir, S.L., Naresh, S.N., Ravindra, K., Basdeo, K. and Satish, K.S. (2010) Toxicity of the herbicide atrazine: effects on lipid peroxidation and activities of antioxidant enzymes in the freshwater fish Channa punctatus. Int. J. Environ. Res. Public Health, 7, 3298-3312.

Clotaire, Y.K. and Nikolaus, G. (1994) Mineralization of the herbicide atrazine as a carbon source by a Pseudomonas strain. Appl. Environ. Microbiol. 121, 4297-4302.

De Souza, M.L., Sadowsky, M.J. and Wackett, L.P. (1996) Atrazine chlorohydrolase from Pseudomonas sp. strain ADP: gene sequence, enzyme purification, and protein characterization. J. Bacteriol. 178, 4894-4900.

Devers, M., Rouard, N. and Martin-Laurent, F. (2007) Genetic rearrangement of the atzAB atrazinedegrading gene cassette from pADP1::Tn5 to the chromosome of Variovorax sp. MD1 and MD2. Gene. 392, 1-6.

El Sebai, T., Devers-Lamrani, M., Changey, F., Rouard, N. and Martin-Laurent, F. (2012) Evidence of atrazine mineralization in a soil from the Nile Delta: isolation of Arthrobacter sp TES6, an atrazine degrading strain. Int. Biodeter. Biodegr. 65, 1249-1255.

Essa, A.M. (2012) Effect of continuous mercury stress on mercury reducing community of some characterized bacterial strains. Afr. J. Microbiol. Res. 6(6), 1255-1261.

Essa, A.M.M., Radwan, T.E.E., Ibrahim, W.M. and Reyad, A.M.M. (2016) Biodegradation of the organophosphorus insecticide diazinon by Pseudomonas aeruginosa isolated from agricultural drainage ditches. Egypt. J. Bot. 56 (1), 353-370.

Kolic, N.U., Hrsak, D., Begonja, K.A., Petric, I., Stipicevic, S., Soulas, G. and Martin-Laurent, F. (2007) Combined metabolic activity within an atrazine-mineralizing community enriched from agrochemical factory soil. Int. Biodeter. Biodegr. 60, 299-307.

Li QY, Li Y, Zhu XK, Cai BL (2008). Isolation and characterization of atrazine-degrading Arthrobacter sp. AD26 and use of this strain in bioremediation 
of contaminated soil. J Environ Sci 20: 1226-1230.

Liu AJ (2003). The isolation of atrazine degrading microbe and the research of degradation characteristics, Shandong agricultural university.

Luciane S, Attilio C, Geslaine ARS, Rita DCGS (2010). New aspects on atrazine biodegradation. Braz Arch Biol Technol 53: 487-496.

Mandelbaum RT, Allan DL, Wackett LP (1995). Isolation and characterization of a Pseudomonas sp. that mineralizes the s-triazine herbicide atrazine. Appl Environ Microbiol 61: 1451-1457.

Moore A, Waring CP (1998). Mechanistic effects of a triazine pesticide on reproductive endocrine function in mature male Atlantic salmon (Salmo Salar L). parr. Pesticide Biochem Physiol 62: 4150 .

Moore MT, Denton DL, Cooper CM, Wrysinski J, Miller JL, Erner I, Horner G, Crane D, Holcomb DB, Huddleston GM (2011). Use of vegetated agricultural drainage ditches to decrease pesticide transport from tomato and alfalfa fields in California, USA. Environ Toxicol Chem 30: 10441049.

Moore MT, Denton DL, Cooper CM, Wrysinski J, Miller JL, Reece K, Crane D, Robins P (2008). Mitigation assessment of vegetated drainage ditches for collecting irrigation runoff in California. J Environ Qual 37: 486-493.

Pathak RK, Dikshit AK (2011). Isolation and characterization of bacterial strains to be used as biosorbent for removal of atrazine from wastewater. 2nd International Conference on Environmental Science and Technology. IPCBEE vol.6. IACSIT Press, Singapore.

Radwan TEE, Reyad AMM, Essa A MM (2017). Bioremediation of the nematicide oxamyl by Enterobacter ludwigii isolated from agricultural wastewater. Egypt. J. Exp. Biol. (Bot.), 13 (3): 19 -30 .

Rousseaux S, Hartmann A, Soulas G (2001). Isolation and characterization of new Gram-negative and Gram-positive atrazine degrading bacteria from different French soils. FEMS Microbiol Ecol 36: 211-222.

Sadowsky MJ, Tong ZK, de Souza M, Wackett LP (1998). AtzC is a new member of the amidohydrolase protein superfamily and is homologous to other atrazine-metabolizing enzymes. J Bacteriol 180: $152-158$.

Sene L, Converti A, Secchi GAR, Simão RDG (2010). New aspects on atrazine biodegradation. Braz Arch Biol Technol 53: 487-496.

Shahitha S (2012). Studies on atrazine mineralization by a consortium of bacteria isolated from sugarcane field soil. J Appl Pharm Sci 2 (06): 223-226

Singh P, Suri CR, Cameotra SS (2004). Isolation of a member of Acinetobacter species involved in atrazine degradation. Biochem Biophys Research comm 317: $697-702$.

Siripattanakul S, Wirojanagud W, McEvoy J, Limpiyakorn T, Khan E (2009). Atrazine degradation by stable mixed cultures enriched from agricultural soil and their characterization. J Appl Microbiol 106: 986-992.

Spalding RF, Snow DD, Cassada DA, Burbach ME (1994). Study of pesticide occurrence in two closely spaced lakes in northeastern Nebraska. J Environ Qual 23: 571-578.

Struthers JK, Jayachandran K, Moorman TB (1998). Biodegradation of atrazine by Agrobacterium radiobacter $\mathrm{J} 14 \mathrm{a}$ and use of this strain in bioremediation of contaminated soil. Appl Environ Microbiol 64: 3368-3375.

Topp E, Zhu H, Nour SM, Houot S, Lewis M, Cuppels D (2000). Characterization of an atrazine-degrading Pseudaminobacter sp. isolated from Canadian and French agricultural soils. Appl Environ Microbiol 66: 2773-2782.

Tyler HL, Khalid S, Jackson CR, Moore MT (2013). Determining potential for microbial atrazine degradation in agricultural drainage ditches. J Environ Qual 42: 828-834 doi:10.2134/ jeq2012.0388.

Udikovic-Kolic N, Hrsak D, Devers M, Klepac-Ceraj V, Petric I, Martin-Laurent F (2010). Taxonomic and functional diversity of atrazine-degrading bacterial communities enriched from agrochemical factory soil. J Appl Microbiol 109: 355-367.

Vibber L, Pressler M, Colores G (2007). Isolation and characterization of novel atrazine-degrading microorganisms from an agricultural soil. Appl. Microbiol. Biot. 75, 921-928.

Wang, G.H., Zhu, L.S., Liu, A.J., Ma, T.Y., Wang, Q., 
Xie, H., Wang, J., Jiang, T. and Zhao, R.S. (2011) Isolation and characterization of an Arthrobacter sp. Strain HB -5 that transforms atrazine. Environ. Geochemist. Health, 33,259-266.

Zhang, Y., Bo, C., Zhao, J., Xiaonan, D., Miao, H., Wang and Z. (2012) Metabolic ability and individual characteristics of an atrazine-degrading consortium. DNC5, J. Hazard, Mater. 238, 376- 381.

\section{وجود بكتيرة " أوكروباكتيرم أورايزا" المحلةة للمبيد العشبي الأترازين في مياه الصرف الزراعي \\ أمانى رياض، شروت رضوان، و ائل ابراهيم* و أشرف عيسى أشئ

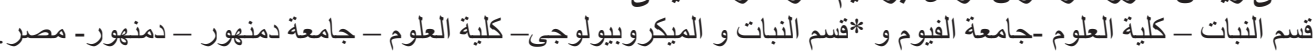

يعتبر الأترازين من أهم المبيدات العشبية السائدة التي تتبع مجموعة إس-أترازين التي تثبط عملية البناء الضوئي للأعشاب

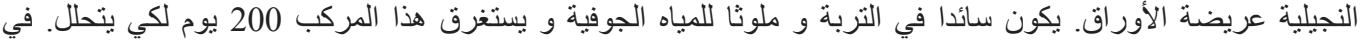

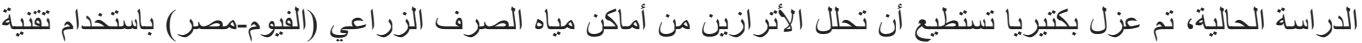

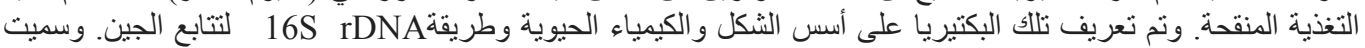

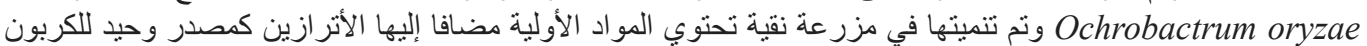

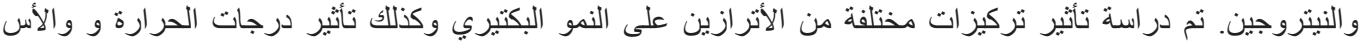

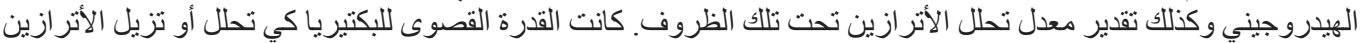

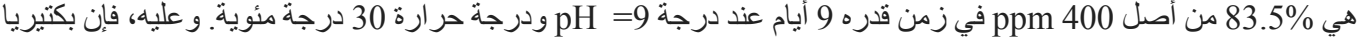

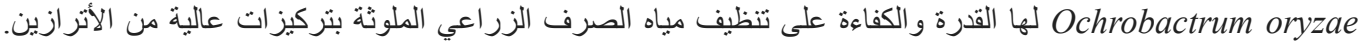


